This item was submitted to Loughborough's Research Repository by the author.

Items in Figshare are protected by copyright, with all rights reserved, unless otherwise indicated.

\title{
The implications of eWOM adoption on the customer journey
}

PLEASE CITE THE PUBLISHED VERSION

https://doi.org/10.1108/JCM-10-2019-3450

PUBLISHER

Emerald Publishing Limited

VERSION

AM (Accepted Manuscript)

PUBLISHER STATEMENT

This paper was accepted for publication in the journal Journal of Consumer Marketing and the definitive published version is available at https://doi.org/10.1108/JCM-10-2019-3450.

\section{LICENCE}

CC BY-NC 4.0

\section{REPOSITORY RECORD}

Ngarmwongnoi, Chananchida, Joao Oliveira, Majd AbedRabbo, and Sahar Mousavi. 2020. "The Implications of Ewom Adoption on the Customer Journey". Loughborough University.

https://hdl.handle.net/2134/12576584.v1. 


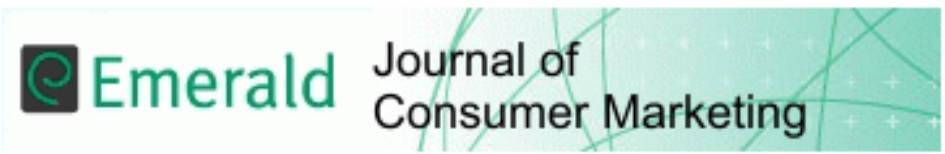

\section{The Implications of eWOM Adoption on the Customer Journey}

\begin{tabular}{|r|l|}
\hline Journal: & Journal of Consumer Marketing \\
\hline Manuscript ID & JCM-10-2019-3450.R2 \\
\hline Manuscript Type: & Regular Paper \\
\hline Keywords: & Electronic word of mouth (eWOM), Social media \\
\hline &
\end{tabular}

SCHOLARONE $^{\text {TM }}$
Manuscripts 


\section{The Implications of eWOM Adoption on the Customer Journey}

\section{Introduction}

The rapid growth of technological advancement has provided consumers with opportunities to interact with firms across multiple channels. The use of these advanced technologies, which is becoming widely accepted by consumers, can influence their experiences throughout the customer journey (Lemon and Verhoef, 2016). The development of social media platforms allows consumers to create electronic word of mouth (eWOM) on online platforms in the form of blogs and vlogs, goods and services reviews, and demonstrations (Liu et al., 2018; Peng et al., 2016). eWOM can be defined as "any positive or negative statement made by potential, actual or former customer which is available to a multitude of people via the internet" (Hennig-Thurau, et al., 2004, p.39). Consumers' desire to socialize, express themselves, and contribute to society (Duan and Dholakia, 2017), encourages them to share their views, experiences and preferences with others in their network to get involved in marketing communications (Trusov et al., 2009). Such activities create usergenerated eWOM that moderates the dynamics of traditional marketing communications between the company and its consumers.

The development of internet technologies increased eWOM communications, which negatively influenced consumers' reliance on traditional marketing communications (Heinonen, 2011). While consumers can perceive companies' advertising to be misleading (Sen and Lerman, 2007), such is less likely to be the case regarding eWOM from other customers and influencers (Rynarzewska, 2019). eWOM is perceived to be more specific and trustworthy as consumers explore real experiences with a product and develop an unbiased opinion (Doh and Hwang, 2009). Hence, eWOM is perceived to be more influential than the opinion of experts and has a stronger impact on the decision-making process (Hussain et al., 2017). 
Consumers seek eWOM to facilitate access to information, secure lower prices, and reduce uncertainty in their purchase decisions (Wang et al., 2015; Lee, 2014). By encouraging social media influencers to share their experiences with the product on social media platforms, companies look to establish consumer-to-consumer interactions across digital platforms that can influence consumers' behavior. Research by Gallagher (2018) estimates that brands' investments on influencers' eWOM will reach $\$ 10$ billion by 2022. Such investments are justified by the high levels of effectiveness of influencers' eWOM activities. Specifically, influencers share organic (i.e., naturally-occurring) and amplified (i.e., marketer-influenced) content such as photos, videos and reviews regarding their experiences with products, which plays a critical role in diversifying the type of information which consumers' hold regarding those products (Kulmala et al. 2013). As such, eWOM provides reassurance to consumers regarding their purchase decisions, thereby influencing their intention to buy products.

While the implications of the adoption of eWOM have been explored, there is limited understanding in terms of the impacts of eWOM on the customer journey. The customer journey consists of the process which a customer goes through, across all stages and touch points, that forms the customer experience (Lemon and Verhoef, 2016) in the context of the purchase of a good/service. There is growing acceptance of the notion that eWOM has a significant impact on the customer journey and its different touchpoints (e.g. Hall et al., 2017). While the more traditional view contends that the customer journey is a linear process, due to eWOM, it is increasingly argued that the customer journey has become a continuous loop in which consumers keep adding and deleting brands as a result of information collected via eWOM (King et al., 2014). Notwithstanding the fact that there is growing evidence that eWOM can have a strong impact during the different stages of the customer journey (Goodrich, and De Mooij, 2014), much is yet to be investigated concerning the specific mechanisms through which eWOM has an impact on the customer journey. This is regrettable as it hinders 
advancement of knowledge regarding the specificities of customer journey in the digital era. The abovementioned shortfall in knowledge is also regrettable from a management standpoint as practitioners need to know whether and how they can use eWOM to shape aspects of the customer journey to boost the performance of their brands.

Against this background, this paper aims to contribute to the literature by investigating not only the motives of consumers to engage with eWOM, but also its effect on consumers' behavior at the purchase and post-purchase stages. This research investigates consumers' motives to search for eWOM, the drivers of consumers' perception towards the information usefulness, and consumer's future intention towards eWOM after they purchase a product as a result of eWOM. In addition, five different types of shoppers based on their purchase behavior after adopting eWOM have been identified. The results of this study help marketers to leverage the usefulness of eWOM as part of their digital marketing communications.

\section{Theoretical background}

\section{1 eWOM and the customer journey}

Prior to the introduction of e-commerce, traditional word of mouth (WOM) was perceived as non-commercial communications between group of consumers who are willing to give feedback to each other on a product to reduce perceived risk (Nyilasy, 2006). The development of online platforms has provided consumers with the opportunity to voluntarily share organic WOM beyond their social groups and help others in their decision-making process (Hussain et al., 2017). Defined as "any positive or negative statement made by potential, actual or former customer which is available to a multitude of people via the internet" (Hennig-Thurau et al.,, 2004, p.39), eWOM can facilitate the speed and convenience of information search due to its permanent online availability. 
With the significant interest of individuals in eWOM, marketers were able to recruit influential people on the internet to create 'amplified' WOM that increases awareness about products, and influence purchase intentions (Kulmala, et al., 2013). By allowing influential people to report their experiences online, marketers are likely to stimulate consumers' interest in their products. The availability of both organic and amplified eWOM has provided consumers with increasing amounts of information that consumers rely on during the decisionmaking process (Cheung et al., 2009).

The customer journey consists of three overall stages, namely pre-purchase, purchase, and post-purchase, as well as multiple touchpoints (Lemon and Verhoef 2016; Neslin et al., 2006). The pre-purchase stage includes all features of the customer's interaction with the brand, category, and environment before the purchase occurs, and involves behaviors such as need recognition, search, and consideration. The purchase stage encompasses all the interactions by the customer with the brand and its environment which occur during the purchase event and includes aspects such as ordering and payment. The post-purchase stage includes customer interactions with the brand and its environment which occur after the purchase, and contains behaviors such as usage and consumption, post-purchase engagement, and service requests (Lemon and Verhoef 2016; Puccinelli et al., 2009).

There is growing acceptance of the notion that eWOM has a significant impact on the overall customer journey and its different stages and touchpoints (e.g. Hall et al., 2017). It is recognized that the ease of access and ubiquity which inherently characterize eWOM may have possibly changed the way in which the customers gather information at each stage (Court et al., 2009;King et al., 2014; Matute et al., 2016; Mudambi and Schuff, 2010). While the more traditional understanding is that the customer journey is a linear process, due to eWOM, it is argued that the customer journey has become a continuous loop in which consumers keep adding and deleting brands due to information gathered through eWOM (King et al., 2014). In 
this context, for instance, there is growing evidence that eWOM can have a strong impact during the different stages of the customer journey (Goodrich, and De Mooij, 2014). Nonetheless, there is much to be learnt regarding the mechanisms via which eWOM affects the different stages of the customer journey.

\subsection{Informational views on eWOM}

eWOM entails a conversation between senders and receivers of information (Bansal and Voyer, 2000). In line with the Theory of Reasoned Action (TRA) (Fishbein and Ajzen, 1975), receivers are likely to develop a reaction to senders' information and act accordingly. Different models have been developed to explain the effect of sharing online information. The Technology Acceptance Model (TAM) (Davis, 1989) is typically used to explain the change in perceptions of consumers following the spread of online information. TAM examines the link between information spreading and changes in consumers' perceptions by examining two components: perceived usefulness and ease of use (Davis, 1989). Despite its wide acceptance, TAM has been criticized in the literature for its limited elaboration on the effect of those two components on consumers' behavior (Erkan and Evans, 2016).

Sussman and Siegal (2003) developed the Information Adoption Model (IAM) to explain how people are influenced by information attained through online communications. The IAM model defends that argument quality and source credibility are critical components of consumers' perceptions of the usefulness of information which determines their level of online information adoption. However, this model solely focuses on the characteristics of information and does not consider consumers' behaviors towards information.

In response to the IAM, Erkan and Evans (2016) developed the Information Acceptance Model (IACM). The model extended the IAM model by incorporating related parts from TRA and proposes information quality, information credibility, need for information, and attitude 
towards information as antecedents of the information usefulness construct. Erkan and Evans (2016) argue that consumers would search for eWOM information across online platforms to help with their decision-making process. Following a check for the quality and credibility of the information, consumers may formulate attitudes towards the eWOM and develop a perception of its usefulness accordingly which would then affect their information adoption and purchase intention.

\subsection{Determinants of eWOM Usefulness}

\subsection{1 eWOM Credibility}

With the development of online platforms, consumers have become exposed to an increasing volume of eWOM (Kim et al., 2018). In this context, the credibility of information has been acknowledged and associated with the degree to which information is perceived as believable (Iyer et al., 2017). Consumers use credibility as a filter check for the usefulness of information (Wathen and Burkell, 2002). They develop positive or negative attitudes towards online information adoption based on their individual perception of this information credibility (Cheung et al., 2009). Credibility of eWOM is judged in terms of appearance, presentation, transparency, and the identity of the person who generates it (Reichelt et al., 2013). Consumers' perceptions towards eWOM quality has a positive effect on their' adoption of information and purchase intentions (Bulut and Karabulut, 2018).

Another dimension of eWOM credibility relates to the perceived expertise of the person who generates it (Willemsen et al., 2012). Consumers are more likely to accept information from those who have significant expertise and knowledge with a product (Ohanian, 1990). The credibility of the individual who generates eWOM has been explored in terms of their followers, views, likes and shares, and has been shown to influence consumers' attitudes and purchase intentions (Freberg et al., 2011; Kim et al., 2018). 


\subsection{2 eWOM Quantity}

Consumers rely heavily on information to obtain reassurance during the decisionmaking process. In online platforms, the volume of eWOM concerning a product constitutes evidence of its popularity among consumers (Fan et al. 2013). The number of online reviews and recommendations act as anchors for purchasing decisions (Lee et al., 2008). As consumers interact with a greater range/volume of information concerning a product, the perceived risk of the purchase decision is reduced because of the increased reassurance offered by such information. Recent work by Bulut and Karabulut (2018) found a correlation between eWOM quantity and purchase intentions. The role of quantity has also been critical for consumers' judgments regarding the credibility of the person who generates eWOM. When such a person has many followers, consumers are likely to perceive him/her as credible and adopt the information (Djafarova and Rushworth, 2017). Therefore, quantity has been largely associated with credibility, information adoption, and purchase intentions (Bataineh, 2015).

\section{Method}

\subsection{Research context}

The data for this research collected from consumers in Thai luxury cosmetics market. The demand on luxury cosmetics in Thailand has been increasing gradually over the years, with the Thai Cosmetic market being considered as the largest market in Southeast Asia (Statista, 2018). While the demand is high for branded products, reports indicate that Thai consumers spend significant time online to develop awareness and evaluate different cosmetic products prior to purchase (Cosmetics Design Asia, 2016). The consumption of luxury goods is relevant with buying a product to symbolize an individual and to impress others (Wiedmann et al., 2009). 
Across Southeast Asia, eWOM is one of the most popular sources of information among consumers, and consumers increasingly trust recommendations provided via eWOM (Nielsen, 2015). Thai people have a significant level of interest in their skincare and, accordingly, spend hours on social media looking for a beauty inspiration prior to buying the desired products. The recent years have witnessed an explosion in the number of Thai beauty influencers who deliver different types of content in online media platforms, such as makeup tutorials and product reviews. The Thai cosmetics market is, thus, an ideal setting to study the effect of eWOM on consumers behavior.

\subsection{Research approach}

This research aims to gain a deeper understanding regarding the perceptions of Thai consumers about the effect of eWOM on their shopping behavior. Therefore, a precise understanding of consumers' experiences and perspectives is required. With this research having an exploratory objective, a qualitative approach (Marshall and Rossman, 2014) in the form of semi-structured interviews was adapted to develop an understanding of the perceptions of Thai consumers towards eWOM and its implications on their behavior.

To ensure consistency of the wording across the interviews, the set of questions was pretested with Marketing and Retailing academics and then checked with native Thai speakers. A pilot study with 5 Thai consumers was conducted to address any concerns with the research questions. In line with the recommendations of Bernard (2000), 30 semi-structured interviews were conducted to achieve good understanding of the research problem. Each interview lasted approximately 40 minutes. The number of interviews and their duration were based on the data saturation approach (Glaser and Strauss, 1967). Accordingly, the data collection process was terminated as further data does not inform new understanding of the research objectives.

Participants were recruited using purposeful sampling. As highlighted by Patton (2002), this sampling approach is appropriate when the aim of the research is not to generalize 
knowledge, but rather to attain an understanding of an emerging phenomenon. Importantly, due to accessibility issues and geographical constraints, Bernard (2000) argue that this technique is suitable when there are difficulties to access participants with articulate experiences about the research problem. Purposive sampling allowed us to attain representation of both genders who were interested in purchasing luxury cosmetics products. Snowball technique was used in this study to reach different consumers who have engaged in eWOM purchases over the past year. Despite its association with selection bias, this technique facilitates the data collection process by targeting people with understanding of the research problem (Churchill, 1999). More females were involved in this study because of the nature of product we are exploring. Most interviewees were aged between 22 and 38 (see appendix) as Thai millennials and generation $\mathrm{Z}$ shoppers display high levels of interest in cosmetics products and in social media interactions (eMarketer, 2016).

The interviews were conducted in Thai language to attain consumers' insights into the research problem using their own words. All interviews were recorded, transcribed and translated into English with the help of native Thai and English speakers. Translations were reviewed by an independent researcher to minimize translation bias. In line with Braun and Clarke (2006), thematic analysis was used to analyze the data as it can help identify patterns within the data to understand the underlying phenomenon. Initial codes and themes were generated individually by each researcher and were cross-checked to achieve reliability in the codes. Chosen themes were selected and clearly defined to finalize the data analysis. A report was produced with the final codes and themes for the purpose of data analysis.

\section{Analysis and results}

\subsection{Research Model}

Based on the coding of the data analysis, we propose a refined model of the IACM (see Figure 1). Components of the model are discussed in the following sections. 
Insert Figure 1 About Here

\subsubsection{Motives to search for eWOM \\ 4.1.1.1 Information validation}

Luxury cosmetics are high involvement products with high perceived risk. The interviewees reported significant interest in researching luxury cosmetic products before making a purchase decision. Their motive to look for information online stems from their desire to make an effective purchase decision. In line with findings from other studies (e.g. Cantallops and Salvi, 2014; Elwalda et al., 2016), when asked about eWOM search, consumers in our sample argued that eWOM is highly important when purchasing cosmetics because they want to know more about the product's ingredients, applications and effects, as well as compare it with alternative products.

While traditional WOM raised awareness about products, it had limited effects on purchase intentions. Instead, at the pre-purchase stage, WOM was found to encourage further engagement with eWOM to verify the information obtained through the former: "Most of the time, it seems like I know about the product from my friends. They recommend me first and I want to make sure whether it's true or not by checking and looking the reviews of a particular product in internet" (Inv-1).

Similarly, at the pre-purchase stage consumers looked at eWOM content which related to product demonstrations and to peer-reviews (e.g. Park and Lee, 2008) in order to see if the messages conveyed by brands in advertisements were indeed realistic.

"Mainly I think the reviewers are the real users because they have before and after pictures to make me clearly understand how particular products can help me, so it motivates me to buy it" (Inv-13). Therefore, it seems consumers are motivated to search for eWOM for 
purposes of content validation. They feel the need to verify any information before engaging with a product.

\subsubsection{Product evaluation}

With the increase of influencers and vloggers on social media platforms, consumers have developed an attitude to engage with eWOM for the purpose of evaluating different products, i.e. to see how different alternatives can be more or less effective considering their particular needs. As eWOM provides an opportunity for consumers to learn about the experiences of real people (Lingreen et al., 2013), consumers are motivated to look for eWOM to evaluate different products before moving to the purchase stage.

"A skin care product, it directly blends into my skin, so I want to make sure that the product really has a good effect for me. That's why I have to look for online reviews" (Inv-3).

Some interviewees who have personal skin concerns such as acne, dark spots, or brightening are likely to search for online reviews and particular products to rapidly overcome their problems.

"I look for reviews to check whether the particular products, especially skincare, have the result effects that I'm looking for or not. And to know which products help to solve my problems at that time" (Inv-7).

\subsubsection{Purchase and post-purchase validation}

Our analysis reveals that some consumers are likely to purchase particular products just after watching video reviews from beauty bloggers and influencers whom they were following, "For me, most of the time I just saw top 10 products must have from famous beauty blogger and I felt that I want to try it' (Inv-29). 
Interestingly, interviewees reported an interest in searching for eWOM after buying a product. This behavior seems to stem from consumers' need to validate the purchase decision they made. Accordingly, after buying the product, consumers seek to validate their purchase decision via checking for eWOM about the product:

"After I buy a product, sometimes, I like to go and search more for reviews online to check what other consumers thought" (Inv-3).

Moreover, the results indicate in the cases where consumers had negative experiences with products bought as a result of eWOM, they were still keen to rely on eWOM for future purchases: "Although I have been allergic in some products I bought from seeing online reviews, I still keep searching and finding other products" (Inv-24), "If the product that I have purchased does not show the good result, I'm going to search for the reviews again to try new one” (Inv-30). This signifies that despite having negative experiences with products purchase as a result of eWOM, consumers still consider eWOM as a powerful source of information (Lee, 2014).

Therefore, our analysis indicates that consumers' motives to search for eWOM spread across the entire customer journey and, as such, eWOM plays a central role in their decisionmaking process.

\subsection{2 eWOM Quantity}

Most of the interviewees identified that the quantity of eWOM affected their purchasing decision process. They linked the quantity to reliability, popularity, and product performance.

Reliability - Interviewees judged the usefulness of information concerning reliability of luxury cosmetics based on the number of reviews.

"If there are many people reviewing this product it means that the product is suitable for many people which may be good to me. I do trust the number of reviewers because it may reduce risk 
as many people have different skin types and everyone claimed it is good. So, the product may be good for everyone" (Inv-8).

Furthermore, with the large amount of online information, consumers look for both positive and negative reviews to reduce the risk associated with the product purchase (Bronner and De Hoog 2011; Rosario et al., 2019). Consumers become aware of the social bias associated with small reviews, so they understand the need to search for a diversity of information before buying it:

"The rating of the reviews is the first factor that affects my purchasing decision. Also, the numbers of reviews. For example, if they have like 5 stars rating but it is only 3-4 people reviewing this product, I may not believe it. It must be more than 10 people reviewing to trust them" (Inv-1).

Popularity - Some interviewees perceived that it is better to have many people discussing the product they are interested in, confirming that the product is currently trending and popular.

"I saw some products that have high volume of reviews. I suddenly know that it is a popular item at that time" (Inv-23).

Product performance - When consumers see eWOM in large numbers, they realize that products could perform satisfactorily for them.

"When there are many people using and reviewing the products, it means that the products are good" (Inv-9).

However, a few interviewees indicated that the quantity of online messages do not affect their purchasing decision, because they are more likely to rely on influencers and the brands themselves. 
"I mostly feel interested in the reviews from famous bloggers who have their background with luxury cosmetics" (Inv-22).

Twenty-three out of 30 interviewees reported the effectiveness of the quantity of eWOM. This is in line with the notion put forward in this research framework that eWOM quantity influences usefulness of information (cf. Gursoy, 2019).

\subsection{3 eWOM Credibility}

The credibility of eWOM is a driver of consumers' perceptions of information usefulness (Erkan and Evans, 2016). Based on our analysis, credibility of eWOM is judged by the author, content and presentation.

\subsubsection{1 eWOM Author}

In line with previous research (e.g. Xu 2014), interviewees in this study associated the credibility of eWOM with the credentials of its author. They judged eWOM authors' credibility based on their knowledge of the product, their experience, and their online popularity. Influencers and beauty bloggers were the most considered source when interviewees searched for product information. Whether the influencers are sponsored or not, the interviewees still rely on their favorite influencers as they have credibility. The longevity of the influencers and beauty bloggers in the reviewing business influence their perceived credibility:

“...the person that I followed is credible because she mostly talks about the ingredients inside particular products and their benefits. So, it seems that she is very knowledgeable unlike the other influencers, they normally discuss general information such as soft texture something like that. Even if she is getting paid from the brand which I know that too, I listen to her. So, I consider the product she recommends first" (Inv-3).

\subsubsection{2 eWOM Presentation and Content}


Consistent with previous research (e.g. Jensen et al., 2013), the data emphasize the effect of presentation in terms of review structure and language used on eWOM credibility. Most interviewees pay attention beyond technical knowledge of the influencer to judge whether this information is useful or not.

"I would see the content and the way the influencer presents something. If they are trying to be too funny, I won't trust them. But, if they are discussing the ingredients and providing knowledge of the product, I may trust them. So, I think they should have reference or evidence to prove" (Inv-11).

A fresh insight emerging from the data relates to the fact that consumers appear to judge the novelty of presentation when assessing the credibility of eWOM. For instance, one interviewee argues that similarities in presentation across bloggers may lead them to question the credibility of the eWOM:

"I have noticed that some influencers talk the same way as other influencers. I think most of the time, they don't have a personality when reviewing a product. I mostly look at influencers who have different ways of presenting the products" (Inv-10).

\subsubsection{3 eWOM level of Engagement}

A few interviewees assessed the credibility of eWOM by the number of views, comments, and followers of a post. Encouraging audiences to participate in online messages can lead to generating credibility of eWOM, which eventually affects consumers' behavior.

"The credibility of reviews in my perspective is the number of views in that review. It may come from reviewers' past experiences, which they can well express and share their useful knowledge to audiences effectively." (Inv-20).

\subsubsection{Attitude towards eWOM}


Attitudes towards eWOM influence how consumers engage with it, as well as their adoption of its content (Erkan and Evans, 2016). On one hand, positive attitudes toward eWOM were apparent in consumers who were interested in any information, regardless of the level of credibility of such information. Those consumers perceive information conveyed in eWOM to be important when making purchase intentions: "I don't have any bad attitudes towards online reviews, it seems like it is significant to keep and study in the future" (Inv-13). On the other hand, consumers who displayed negative attitudes toward eWOM believed that eWOM is unimportant to their decisions as eWOM is mainly sponsored and intended for marketing purposes: "If I found a positive messages with many descriptions of a product, I will immediately think is it advertisement or sponsored post" (Inv-25). In line with TRA, consumers attitudes towards eWOM would influence their perception of the usefulness of information (Erkan and Evans, 2016).

\subsubsection{Information Usefulness and Adoption}

Information usefulness refers to individuals' perception that using new information will improve and enhance their performance (Hussain et al., 2017). Respondents found eWOM information useful because it provides them with information/knowledge about product. Whether the eWOM is positive or negative, interviewees tended to agree that eWOM generated by real people is more beneficial than information generated by the brand.

"I think it is useful for me. In brand advertisements, I only know one side from the brand that they want to present but in the reviews from the internet, I can know every single detail deeply from their real experiences with understandable message rather than a formal language" (Inv23).

Some interviewees found that the information was beneficial in terms of saving time and offering promptitude: “...it is quick and fast to search just by some keywords; I will know 
exactly what I need" (Inv-19).

\subsubsection{Implications of eWOM on Consumer Behavior}

In line with the TRA (Fishbein and Ajzen, 1975), consumers are likely to react differently according to the eWOM they are exposed to. Results suggest that consumers can be categorized into five different types of shoppers, depending on their behaviors following eWOM adoption: prompt shoppers, at-store shoppers, promotion savvy shoppers, conservative shoppers, and remedy shoppers.

\subsubsection{Prompt shoppers}

This type of shoppers develops a strong interest in buying a reviewed product without trying a tester first. Their desire to learn more about a product and verify others' experiences with it develops positive attitudes towards products and so their purchase intentions. This is particularly important in the case of cosmetics products as prompt shoppers are excited about trying it on their skin. It is noteworthy that prompt shoppers reported limited skin sensitivity, which encourages them to try new products easily: "My skin is not that sensitive, so I just buy it immediately" (Inv-1).

\subsubsection{In-store shoppers}

eWOM encourages in-store shoppers to search for the product in-store before buying it. They are likely to engage with a salesperson and ask to try the product on their skin first to assess the reliability of the adopted eWOM: "If the particular product that I'm interested in has a physical store in Thailand, I will go to try out and talk with a beauty advisor again before purchasing" (Inv-25). Sometimes they ask for the sample to try it first before purchasing: "I went to the counter to ask for the sample... and after I finish the sample, if it is good and fits my skin, I will buy it” (Inv-28). 


\subsubsection{Promotion savvy shoppers}

Once they hear about a product online, these shoppers conduct further research into the product price and availability of price promotions. If the reviewed product is under a price promotion (i.e. if it is being sold at a discounted price), promotion savvy consumers would likely engage in a purchase to test the advantages of the product and reduce the perceived risk: "Before buying, I'm going to check the promotion first" (Inv-2). Some consumers mentioned their willingness to wait for a product to go on promotion before buying it.

\subsubsection{Conservative shoppers}

This group is least likely to be influenced by eWOM. Despite their interest in eWOM, they tend to buy their trusted products if those are available. This behavior stems for their riskaverse approach when buying luxury items: "if the old product is about to finish, I'm going to buy it, in case new products are not better than the old one" (Inv-16). Conservative shoppers would engage in new product purchase if such the new product is better than their existing product. However, they are likely to research it heavily and try it first before making a purchase.

\subsubsection{Remedy shoppers}

Remedy shoppers are motivated to search online about a skin-care product if they need a solution to an existing problem. Like prompt shoppers, remedy shoppers will engage with a purchase immediately if the eWOM they are exposed to indicates that the product constitutes a solution to their problem: "If I have a [skin] problem at the moment, I will buy it promptly" (Inv-7).

\section{Discussion}

\subsection{Theoretical implications}


This study provides several implications for theory development. While the literature acknowledges the significant impact of eWOM on the customer journey (Hall et al., 2017), much is yet to be known regarding the specific mechanisms via which eWOM affects the customer journey.

Building on the IACM model (Erkan and Evans, 2016), this research developed a model considering the impact of eWOM throughout the customer journey. Specially, we identified consumers' motive to search for eWOM, the drivers of consumers' perception towards the information usefulness, and consumer's future intention towards eWOM after they purchase a product as a result of eWOM.

In terms of the antecedents of usefulness of information, our findings support Bulut and Karabulut (2018) and Fan et al's (2013) contention that quantity of eWOM plays an important role in developing consumers' perceptions towards the usefulness of eWOM. In this context, the number of reviews of a product can be critical in determining its popularity (Fan et al., 2013), and influencers' credibility is often judged based on the number of subscribers (Djafarova and Rushworth, 2017). In line with Freberg et al. (2011), this study shows that the number of shares, likes and views constitute indicators of eWOM credibility.

Wathen and Burkell (2002) argue that the notion of credibility is subjective and, as such, different consumers have different perceptions regarding credibility. In this study, we find that consumers judge the credibility of eWOM along different aspects: the expertise of the author who generated the eWOM, its presentation and content, and the level of engagement of other users with it. This finding conforms to Hussain et al (2017)'s who argue expertness, trustworthiness and objectivity as key dimensions of eWOM credibility.

Respondents in our study exhibited different attitudes and beliefs towards eWOM. While some consumers perceive it as useful, others were more skeptical and argued that it is merely a mechanism generated by marketers to influence purchase decisions. This finding is 
in contrast with Kozinets et al's(2010) study where the authors report that consumers perceive eWOM as organic, rather than as a marketing tactic. We find that the role of eWOM spreads across the entire customer journey, and that consumers may develop different attitudes towards eWOM within and across stages. For instance, consumers may have positive attitudes towards eWOM in the awareness phase of the pre-purchase stage as they perceive information as a source of knowledge. However, this perception may change during the product evaluation phase of the pre-purchase stage, since perceived risk of eWOM is greater at this latter stage.

Moreover, this study outlines five different categories of shoppers following the adoption of eWOM. Prompt shoppers tend to move immediately to the purchase stage when exposed to positive eWOM recommendations. This contrasts with conservative shoppers who are reluctant to immediately purchase a product simply because it is recommended through eWOM. Our findings also identify remedy and promotion shoppers who would develop intentions to purchase eWOM promoted products because of individual reasons such as having skin problems at the time and looking to solve it quickly, and unavailability of preferred products. Such reasons influence consumers perceived risks and benefits of eWOM promoted products, which consequently affect their purchase behavior. Finally, we identify in-store shoppers who prefer to try a product before purchasing and often ask the seller to confirm the information.

This study provides further understanding on the effect of buying products that are promoted via eWOM, on future consumer behaviors. A puzzling finding unveiled in this study relates to the fact that, regardless of consumers experience with the purchase products, they are likely to engage with eWOM at the post-purchase stage in order to validate their purchase decision, to compare and contrast their experiences with others, or to find out about new products. It was particularly surprising to find that consumers with negative product experiences still showed a high interest in eWOM, despite the increase in their perceptions of 
risk regarding such information (which is likely to occur due to the negative experience with the product). This can be due to inertia, consumers often pay little attention to a negative eWOM experiences, which leads them to re-trust eWOM even after those experiences (Lee, 2014). This finding supports the notion that eWOM acts both as an input and as an output of the decision-making process of consumers (Shin and Chung, 2017).

\subsection{Managerial implications}

The findings of this study provide several insights for marketers into the implications of eWOM on consumer behavior. Marketers need to be aware that consumers perspectives towards traditional advertisement and WOM has changed and they rely heavily on eWOM throughout the entire customer journey, from pre-purchase to post-purchase (Court et al., 2009; Matute et al., 2016). The quantity and credibility of eWOM play a significant role in determining the usefulness of information. Consumers examine eWOM beyond technical knowledge of the influencers to make purchase decisions (Jensen et al.,2013; Xu 2014). As such, in order to leverage consumers' experience throughout the different stages of the customer journey, brands which invest in online influencers and endorsements need to carefully assess the expertise of the influencers and evaluate how consumers perceive them. Moreover, brand managers should pay more attention to the presentation and content of their online information to make it more credible and easier for consumers to engage with.

Importantly, marketers need to be aware of the role of eWOM on future consumers' behavior in the post-purchase stage of the customer journey. Consumers go online seeking further reassurance regarding their purchase decision. The presence of positive reviews of the product can reduce the perceived risk of purchase and encourage positive behavior in the future (Lee, 2014; See-To and Ho, 2014). Therefore, marketers need to create amplified eWOM that provides reassurance for consumers at this critical stage of the journey, so as to encourage 
positive behaviors (e.g. enhanced brand loyalty, lack of returns/exchanges of the product, consumer engagement in positive eWOM post-purchase).

This study outlines different types of shoppers following the adoption of eWOM. Each category of shopper tends to be influenced by the perceived risk and benefits of eWOM promoted products before buying it. By understanding the motives of these different types of consumers, marketers can analyze purchase patterns of their consumers and create personalized experiences that can encourage positive behavior towards the brand in the future.

\section{Limitations and future research recommendations}

The findings of this study open scope for future research on the implications of eWOM on consumer behavior. While the study used qualitative research to gain insights into the research problem, the sample size and demographic of participants can be extended. Further quantitative research can investigate the relationships proposed in our model.

This study focused on luxury cosmetics in one specific developing market (Thailand). Future research can focus on other emerging countries and/or industries to assess whether the findings attained in this study hold in other markets/industries. Finally, we found that having negative post-purchase experiences with products that have been recommended via eWOM does not seem to affect consumers' future behavior regarding eWOM information adoption. This is surprising as the perceived risk of purchases driven by eWOM should increase as a result of a negative post-purchase experience. Hence, future research can explore possible reasons for this finding. 


\section{References}

Bansal, H. S. and Voyer, P. A. (2000). Word-of-mouth processes within a services purchase decision context. Journal of service research, Vo. 3, No. 2, pp. 166-177.

Bataineh, A. (2015). The Impact of Perceived e-WOM on Purchase Intention: The Mediating Role of Corporate Image. International Journal of Marketing Studies, Vol. 7, No. 1, pp. 126137.

Bernard, H.R. (2000). Social research methods. Thousand Oaks, CA: Sage.

Braun, V. and Clarke, V. (2006). Using thematic analysis in psychology. Qualitative Research in Psychology, Vol. 3, No.2), pp.77-101.

Bronner, F., and De Hoog, R. (2011). Vacationers and eWOM: Who posts, and why, where, and what?. Journal of Travel Research, Vol. 50, No. 1, pp. 15-26.

Bulut, Z.A. and Karabulut, A.N. (2018). Examining the role of two aspects of eWOM in online repurchase intention: An integrated trust-loyalty perspective. Journal of Consumer Behaviour, Vol. 17, No. 4, pp. 407-417.

Cantallops, A. S., and Salvi, F. (2014). New consumer behavior: A review of research on eWOM and hotels. International Journal of Hospitality Management, Vol. 36, pp. 41-51.

Cheung, M. Y., Luo, C., Sia, C. L. and Chen, H. (2009). Credibility of electronic word-ofmouth: Informational and normative determinants of on-line consumer recommendations. International journal of electronic commerce, Vol. 13, No. 4, pp. 9-38.

Churchill, G. A. (1999). Marketing research: Methodological foundations. 7th ed. Harcourt Brace, Orlando, Fl.

Cosmetics-design-asia. (2016). Thailand to focus on increasing cosmetic growth by up to $10 \%$. [online], Available at: https://www.cosmeticsdesign-asia.com/Article/2016/09/28/Thailandto-focus-on-increasing-cosmetic-growth-by-up-to-10 (Accessed 22 April 2019).

Court, D., Elzinga, D., Mulder, S. and Vetvik, O.J., (2009). The consumer decision journey. McKinsey Quarterly, Vol. 3, No. 3, pp. 96-107. 
Davis, F. D. (1989). Perceived usefulness, perceived ease of use, and user acceptance of information technology. MIS quarterly, pp. 319-340.

Djafarova, E. and Rushworth, C. (2017). Exploring the credibility of online celebrities' Instagram profiles in influencing the purchase decisions of young female users. Computers in Human Behavior, Vol. 68, pp.1-7.

Doh, S. and Hwang, J. (2009). How Consumers Evaluate eWOM (Electronic Word-of-Mouth) Messages. CyberPsychology \& Behavior, Vol. 12, No. 2, pp. 193-197.

Duan, J., and Dholakia, R. R. (2017). Posting purchases on social media increases happiness: the mediating roles of purchases' impact on self and interpersonal relationships. Journal of Consumer Marketing, Vol. 34, No. 5, pp. 404-413.

Elwalda, A., Lü, K., and Ali, M. (2016). Perceived derived attributes of online customer reviews. Computers in Human Behavior, Vol. 56, pp. 306-319.

eMarketer.com. (2016). Internet User Penetration in Thailand, by Age, March 2016 (\% of population in each group) - eMarketer. [online] Available at: https://www.emarketer.com/Chart/Internet-User-Penetration-Thailand-by-AgeMarch-2016of-population-each-group/203957 (Accessed 25 March 2018).

Erkan, I. and Evans, C. (2016). The influence of eWOM in social media on consumers' purchase intentions: An extended approach to information adoption. Computers in Human Behavior, Vol. 61, pp. 47-55.

Fan, Y. W., Miao, Y. F., Fang, Y. H. and Lin, R. Y. (2013). Establishing the adoption of electronic word-of-mouth through consumers' perceived credibility. International Business Research, Vol. 6, No.3, pp. 58-65.

Fishbein, M. and Ajzen, I. (1975). Belief, attitude, intention and behavior: An introduction to theory and research. Reading, MA: Addison-Wesley.

Freberg, K., Graham, K., McGaughey, K. and Freberg, L. (2011). Who are the social media influencers? A study of public perceptions of personality. Public Relations Review, Vol. 37, No. 1, pp. 90-92. 
Gallagher, K., (2018). The Influencer Marketing Report: research, strategy and platforms for leveraging social media influencers. Business Insider.

Glaser, B. and Strauss, A. (1967). The discovery of grounded theory: Strategies for qualitative research. New York: Aldine Publishing Company.

Goodrich, K., and De Mooij, M. (2014). How 'social' are social media? A cross-cultural comparison of online and offline purchase decision influences. Journal of marketing communications, Vol. 20, No. 1-2, pp. 103-116.

Gursoy, D. (2019). A critical review of determinants of information search behavior and utilization of online reviews in decision making process (invited paper for 'luminaries' special issue of International Journal of Hospitality Management). International Journal of Hospitality Management, Vol. 76, pp. 53-60.

Hall, A., Towers, N., and Shaw, D. R. (2017). Understanding how Millennial shoppers decide what to buy. International Journal of Retail and Distribution Management, Vol.45, No. 5, pp. 498-517.

Heinonen, K. (2011). Consumer activity in social media: Managerial approaches to consumers' social media behavior. Journal of Consumer Behaviour, Vol. 10, No. 6, pp. 356-364.

Hennig-Thurau, T., Gwinner, K.P., Walsh, G. and Gremler, D.D., (2004). Electronic word-of-mouth via consumer-opinion platforms: What motivates consumers to 65 articulate themselves on the Internet? Journal of Interactive Marketing, Vol. 18, No. 1, pp. 38-52.

Hussain, S., Ahmed, W., Jafar, R.M.S., Rabnawaz, A. and Jianzhou, Y. (2017). eWOM source credibility, perceived risk and food product customer's information adoption. Computers in Human Behavior, Vol. 66, pp. 96-102.

Iyer, P., Yazdanparast, A., and Strutton, D. (2017). Examining the effectiveness of WOM/eWOM communications across age-based cohorts: implications for political marketers. Journal of Consumer Marketing, Vol. 34, No. 7, pp. 646-663.

Jensen, M. L., Averbeck, J. M., Zhang, Z., and Wright, K. B. (2013). Credibility of anonymous online product reviews: A language expectancy perspective. Journal of Management Information Systems, Vol. 30, No. 1, pp. 293-324. 
Kim, S., Kandampully, J. and Bilgihan, A. (2018). The influence of eWOM communications: An application of online social network framework. Computers in Human Behavior, Vol. 80, pp. 243-254.

King, R. A., Racherla, P., and Bush, V. D. (2014). What we know and don't know about online word-of-mouth: A review and synthesis of the literature. Journal of interactive marketing, Vol. 28, No. 3, pp. 167-183.

Kozinets, R., de Valck, K., Wojnicki, A. and Wilner, S. (2010). Networked Narratives: Understanding Word-of-Mouth Marketing in Online Communities. Journal of Marketing, Vol. 74, No. 2, pp. 71-89.

Kulmala, M., Mesiranta, N., and Tuominen, P. (2013). Organic and amplified eWOM in consumer fashion blogs. Journal of Fashion Marketing and Management: An International Journal, Vol. 17, No. 1, pp. 20-37.

Lee, J., Park, D. and Han, I. (2008). The effect of negative online consumer reviews on product attitude: An information processing view. Electronic Commerce Research and Applications, Vol. 7, No. 3, pp. 341-352.

Lee, M., Rodgers, S. and Kim, M. (2009). Effects of valence and extremity of eWOM on attitude toward the brand and website. Journal of Current Issues \& Research in Advertising, Vol. 31, No. 2, pp. 1-11.

Lee, Y. C. (2014). Impacts of decision-making biases on eWOM retrust and risk-reducing strategies. Computers in Human Behavior, Vol. 40, pp. 101-110.

Lemon, K. N. and Verhoef, P. C. (2016). Understanding customer experience throughout the customer journey. Journal of marketing, Vol. 80, No. 6, pp. 69-96.

Lingreen, A., Dobele, A., Vanhamme, J., Abrantes, J. L., Seabra, C., Lages, C. R., and Jayawardhena, C. (2013). Drivers of in-group and out-of-group electronic word-of-mouth (eWOM). European Journal of Marketing, Vol.47, No. 7, pp. 1067-1088

Liu, S. Q., Ozanne, M., and Mattila, A. S. (2018). Does expressing subjectivity in online reviews enhance persuasion? Journal of Consumer Marketing, Vol. 35, No. 4, pp. 403-413. 
Marshall, C. and Rossman, G. (2014). Designing qualitative research. SAGE Publications.

Matute, J., Polo-Redondo, Y., and Utrillas, A. (2016). The influence of EWOM characteristics on online repurchase intention. Online Information Review, Vol. 40, No. 7, pp. 1090-1110.

Mudambi, S. M., and Schuff, D. (2010). Research note: What makes a helpful online review? A study of customer reviews on Amazon. com. MIS quarterly, pp. 185-200.

Neslin, S. A., Grewal, D., Leghorn, R., Shankar, V., Teerling, M. L., Thomas, J. S., and Verhoef, P. C. (2006). Challenges and opportunities in multichannel customer management. Journal of Service Research, Vol. 9, No. 2, pp. 95-112.

Nielsen.com. (2015). Word-of-Mouth Recommendations Remain the Most Credible. Available at:https://www.nielsen.com/id/en/press-releases/2015/word-of-mouth-recommendationsremain-the-most-credible/ (Accessed 24 March 2020).

Nyilasy, G. (2006). "Word of mouth: what we really know- and what we don't". In Kirkby, J. and Marsden, P. (Eds), Connected marketing: The Viral Buzz and Word of Mouth Revolution: Oxford: Butterworth-Heinemann. pp. 161-184

Ohanian, R. (1990). Construction and validation of a scale to measure celebrity endorsers' perceived expertise, trustworthiness, and attractiveness. Journal of Advertising, Vol. 19, No. 3, pp. 39-52.

Park, D. H., and Lee, J. (2008). eWOM overload and its effect on consumer behavioral intention depending on consumer involvement. Electronic Commerce Research and Applications, Vol. 7, No. 4, pp.386-398.

Patton, M.Q., (2002). Two decades of developments in qualitative inquiry: A personal, experiential perspective. Qualitative social work, Vol. 1, No. 3, pp. 261-283.

Peng, L., Cui, G., Zhuang, M., and Li, C. (2016). Consumer perceptions of online review deceptions: an empirical study in China. Journal of Consumer Marketing, Vol 33, No. 4, pp. 269-280.

Puccinelli, N. M., Goodstein, R. C., Grewal, D., Price, R., Raghubir, P., and Stewart, D. (2009). Customer experience management in retailing: understanding the buying process. Journal of Retailing, Vol. 85, No. 1, pp. 15-30. 
Reichelt, J., Sievert, J. and Jacob, F. (2013). How credibility affects eWOM reading: The influences of expertise, trustworthiness, and similarity on utilitarian and social functions. Journal of Marketing Communications, Vol. 20, No. 1-2, pp. 65-81.

Rosario, A. B., de Valck, K., and Sotgiu, F. (2019). Conceptualizing the electronic word-ofmouth process: What we know and need to know about eWOM creation, exposure, and evaluation. Journal of the Academy of Marketing Science, pp. 1-27.

Rynarzewska, A. I. (2019). It's not fake, it's biased: insights into morality of incentivized reviewers. Journal of Consumer Marketing, Vol. 36, No. 3, pp. 401-409.

See-To, E. W. and Ho, K. K. (2014). Value co-creation and purchase intention in social network sites: The role of electronic Word-of-Mouth and trust-A theoretical analysis. Computers in Human Behavior, Vol. 31, pp. 182-189.

Sen, S. and Lerman, D. (2007). Why are you telling me this? An examination into negative consumer reviews on the Web. Journal of Interactive Marketing, Vol. 21, No.4, pp. 76-94.

Shin, D. H. and Chung, K. M. (2017). The effects of input modality and story-based knowledge on users' game experience. Computers in Human Behavior, Vol. 68, pp. 180-189.

Statista. (2018). Cosmetics - Thailand | Statista Market Forecast. [online] Available at: https://www.statista.com/outlook/70010000/126/cosmetics/thailand\# (Accessed 22 Mar. 2018).

Sussman, S. W. and Siegal, W. S. (2003). Informational influence in organizations: An integrated approach to knowledge adoption. Information systems research, Vol.14, No.1, pp. 47-65.

Trusov, M., Bucklin, R. E. and Pauwels, K. (2009). Effects of word-of-mouth versus traditional marketing: findings from an internet social networking site. Journal of Marketing, Vol. 73, No.5, pp. 90-102.

Wang, S., Cunningham, N. R., and Eastin, M. S. (2015). The impact of eWOM message characteristics on the perceived effectiveness of online consumer reviews. Journal of Interactive Advertising, Vol. 15, No.2, pp. 151-159. 
Wathen, C. and Burkell, J. (2002). Believe it or not: Factors influencing credibility on the Web. Journal of the American Society for Information Science and Technology, Vol. 53, No. 2, pp. 134-144.

Wiedmann, K., Hennigs, N. and Siebels, A. (2009). Value-based segmentation of luxury consumption behavior. Psychology and Marketing, Vol. 26, No.7, pp. 625-651.

Willemsen, L. M., Neijens, P. C., and Bronner, F. (2012). The ironic effect of source identification on the perceived credibility of online product reviewers. Journal of ComputerMediated Communication, Vol. 18, No. (1), pp. 16-31.

Xu, Q. (2014). Should I trust him? The effects of reviewer profile characteristics on eWOM credibility. Computers in Human Behavior, Vol. 33, pp. 136-144. 
Figure 1: The Proposed Research Model

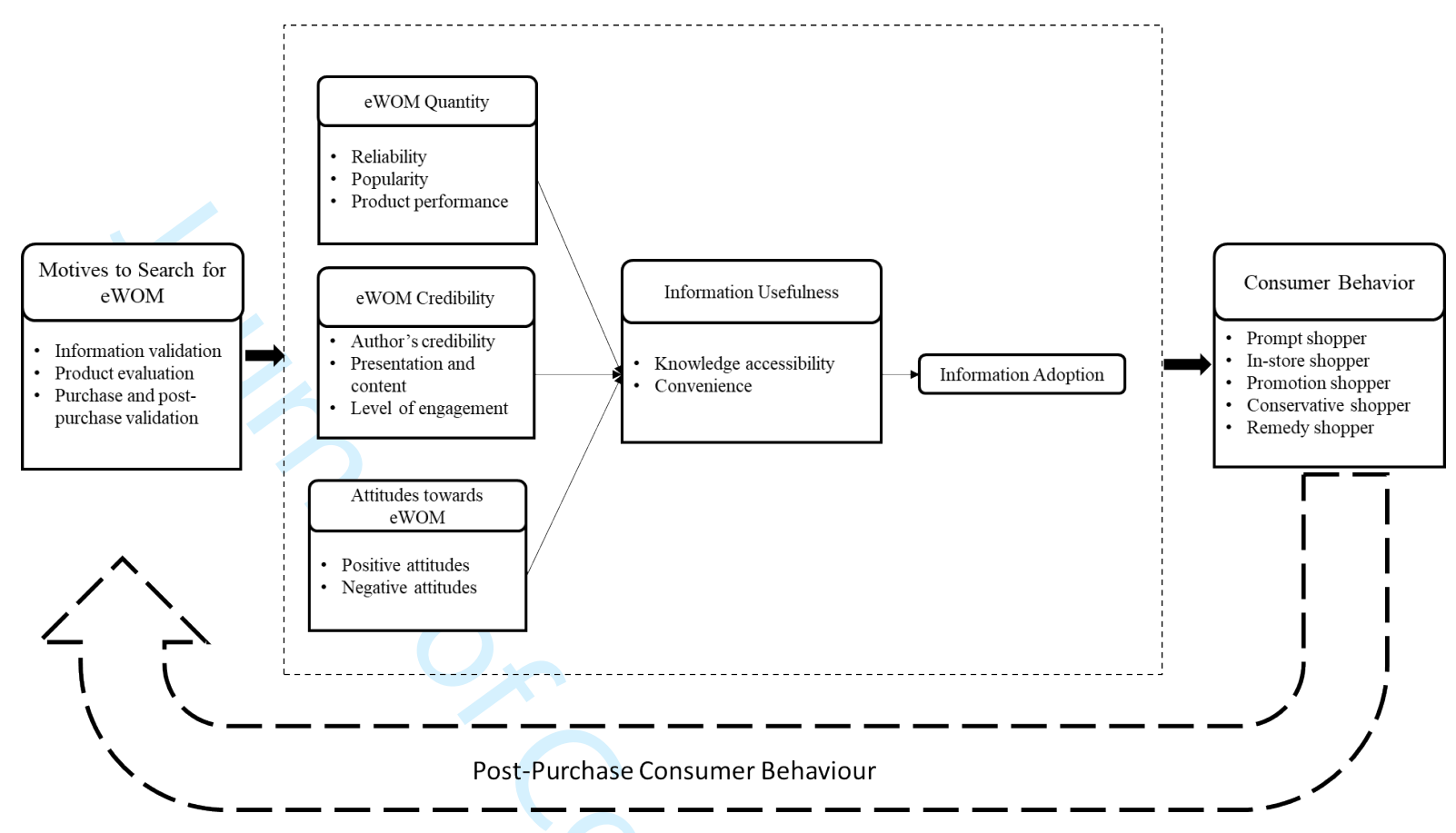


Appendix: Coding Scheme for Interviewees

\begin{tabular}{|c|c|c|c|c|c|}
\hline Inv. No & Gender & Age & Inv. No & Gender & Age \\
\hline Inv-1 & Female & 25 & Inv-16 & Male & 38 \\
\hline Inv-2 & Female & 25 & Inv-17 & Female & 23 \\
\hline Inv-3 & Female & 25 & Inv-18 & LGBT & 27 \\
\hline Inv-4 & Female & 25 & Inv-19 & Female & 24 \\
\hline Inv-5 & Female & 23 & Inv-20 & Male & 24 \\
\hline Inv-6 & Female & 27 & Inv-21 & Female & 24 \\
\hline Inv-7 & Female & 24 & Inv-22 & Male & 32 \\
\hline Inv-8 & Female & 25 & Inv-23 & Female & 25 \\
\hline Inv-9 & Female & 23 & Inv-24 & Female & 26 \\
\hline Inv-10 & Female & 24 & Inv-25 & Female & 23 \\
\hline Inv-11 & Female & 25 & Inv-26 & Female & 22 \\
\hline Inv-12 & Female & 24 & Inv-27 & LGBT & 23 \\
\hline Inv-13 & Female & 25 & Inv-28 & Male & 25 \\
\hline Inv-14 & Male & 24 & Inv-29 & Female & 28 \\
\hline Inv-15 & LGBT & 25 & Inv-30 & Male & 25 \\
\hline
\end{tabular}

